\title{
Meteorological Safety of Entering Eastern Adriatic Ports
}

\section{Ružica Popovića, Mirsad Kulović ${ }^{b}$, Tatjana Stanivuk ${ }^{c}$}

Traffic and sea shipping industry are perhaps the most important economic activities in modern economic and social development of the world. Basic features and the meaning of sea shipping industry, as one of the constituent parts of multimodal transport, emerge primarily from special characteristics of the sea as a transportation way.

Ports represent a great economic power; they play an essential role in the international and national economies, as well as in the global commodity exchange. They are of special importance because they are primary starting points for marine economy development. Numerous factors are relevant for the role and development of ports and port systems, and the most important ones include natural characteristics of ports, such as the depth and spatiality of the port maritime zone, shelter from winds, waves, sea currents and tides, and climate features.

\section{KEY WORDS}

$\sim$ Multimodal Contemporary Transport

$\sim$ Sea Shipping Industry

$\sim$ Ports

$\sim$ Marine Meteorology

$\sim$ Climate

$\sim$ Wind

$\sim$ Wind Roses

\author{
a. Meteorological and Hydrological Service, Department of Marine Meteorology, \\ Split, Croatia \\ e-mail: popovic@cirus.dhz.hr \\ b. College for Traffic Engineering, Pan-European APEIRON University, Banja Luka, \\ Bosnia and Herzegovina \\ e-mail:m.kulovic@hotmail.com \\ c. University of Split, Faculty of Maritime Studies, Split, Croatia \\ e-mail: tstanivu@pfst.hr
}

The recognition of the importance of meteorology for maritime activities has even changed the schooling of seamen; educational programmes have been adjusted according to WMO recommendations, ships have been equipped with the state-ofthe-art meteorological and navigational devices, and once the satellites were introduced the meteorological service has reached a high level of development and forecast accuracy. Therefore, marine meteorology should not be neglected; it should be given as much importance so as to become a constituent part of the skill for choosing the best and optimal shipping route.

Marine meteorology (which includes the river meteorology as well) provides weather information to various maritime and river transportation activities. First of all, it refers to information on the state of wind and sea. Considering the importance of understanding the weather and climate of the area where a port is located, this paper provides a detailed overview of the climatological elements, including wind roses, for each of the presented ports: Rijeka, Zadar (Gaženica), Split (North Port), Ploče and Dubrovnik (Gruž). 


\section{INTRODUCTION}

Multimodal transport, as a modern means of the transportation of goods, is a combined transport which efficiently involves almost all transport branches (means) and modern transportation technologies across the international shipping routes. Unlike conventional or unimodal transport, multimodal transport means the carriage of goods by at least two different modes of transport. It never exists as a specialised or independent mode as it represents a complex system within the international shipping environment.

Transportation of various goods, cargo and passengers by modern infrastructural and suprastructural facilities, and the multimodal operators that directly affect the safety, speed and cost-efficiency of the manipulation and transportation of cargo, represent the main participants in providing transport services in all modes of transport, including the multimodal transport.

One of the major aspects of multimodal transport is the maritime shipping and the sea ports as the departure or arrival points that handle a part of the route between the cargo's starting to final destinations. Basic features and the meaning of sea shipping industry arise primarily from the fact that the sea is a huge transportation way and that seaborne trade accounts for almost three fourths of the global trade. Croatian seaports play a significant role in the national and regional trade. Their importance is based on the favourable geographical position. The long and indented eastern Adriatic coast is home to a number of smaller and larger ports. With regard to transportation of cargo and passengers, the five largest ports include Rijeka, Zadar, Split, Ploče and Dubrovnik.

The Adriatic Sea is the northernmost arm of the Mediterranean Sea penetrating deeply into the European mainland between the long shorelines of Italy and Croatia. Therefore, the Adriatic is the part of the Mediterranean which is the closest and most accessible to Central Europe. Its eastern coast, the Croatian side of the Adriatic, is the most indented part of the sea, comprising a total of 1185 islands, islets, rocks and underwater rocks. The shore length amounts to $5835 \mathrm{~km}$. The sea surface area covers $138,595 \mathrm{~km}^{2}$, with a maximum depth of 1330 metres (southern Adriatic basin) and an exceptional water transparency up to a depth of 50 metres.

\section{METEOROLOGICAL SAFETY OF NAVIGATION}

In order to be safe, cost-efficient and operational in all segments, a port has to meet all requirements for unobstructed loading, unloading, embarking and disembarking, but first and foremost, it has to be safe for sailing in and out. The safety of the approaching manoeuvre is largely affected by meteorological and climatological conditions prevailing in the area. These conditions primarily imply the state of the sea and winds.
When designing and constructing any type of the vessel or port, it is obligatory to take into account relevant meteorological elements, phenomena and their side effects. It is also necessary to anticipate the (im)possibility of using the port during certain days or periods over the year, and to define the approaching routes and fairways. The wind force and direction, which are closely related to the development of heavy seas, as well as impaired visibility (fog), may be the limiting factors in the port operation processes. Therefore all branches of navigation and port development require meteorological information, as a number of meteorological phenomena have been detected due to sea accidents. When determining the position and layout of a port, it is considered as good practice to maintain the natural surroundings that decrease the adverse effects of winds and waves. Along the eastern Adriatic coast there are a number of ports that provide excellent shelter from the wind and seas coming from one direction, whereas they are poorly protected against waves and wind coming from another direction. This particularly refers to the north-easterly and south-easterly winds (bora and sirocco).

The type and size of every vessel determine its seaworthiness. The safety of navigation, anchoring and berthing is at risk when crucial meteorological conditions, which are determined as meteorological minima for ports, vessels, phases of navigation and participants in maritime traffic, are exceeded. Many of these minima have not been determined by meteorological measurements or separate analyses; instead, they rely on assessment and experience and are within the competence of the harbour master's office and/or deck officers.

Non-navigational weather conditions refer primarily to anchoring and mooring of vessels. Under these conditions the vessel and her cargo or passengers should be protected against adverse effects of meteorological and oceanological processes including gale, storm, discharge of electricity, waves, currents, high and low tides, and the like.

\section{CLIMATOLOGICAL ANALYSIS}

Unobstructed performance of traffic in the ports at the eastern coast of the Adriatic Sea requires, among other things, the familiarisation with the prevailing meteorological and climatological conditions in the port area. As it is necessary to meet all safety requirements for the safe operation of maritime traffic, including the meteorological ones, the analysis of climatological elements should be made for five ports at the eastern coast of the Adriatic: Rijeka, Zadar, Split, Ploče and Dubrovnik. The climatological analysis of meteorological parameters relevant for the unobstructed flow of maritime traffic reveals the statistical safety of the individual ports. 


\subsection{Port of Rijeka}

Croatia's largest seaport is the port of Rijeka which handles, on average, over $50 \%$ of all port traffic. The analysis of climatological elements has produced the following results:

Table 1.

Number of days with strong breeze ( $\geq 6 \mathrm{Bf}$ ) and gale force wind ( $\geq 8 \mathrm{Bf})$, number of days with fog and the wind rose for the area of Rijeka, according to the data referring to the period from 2003 to 2012.

\section{RIJEKA 2003-2012}

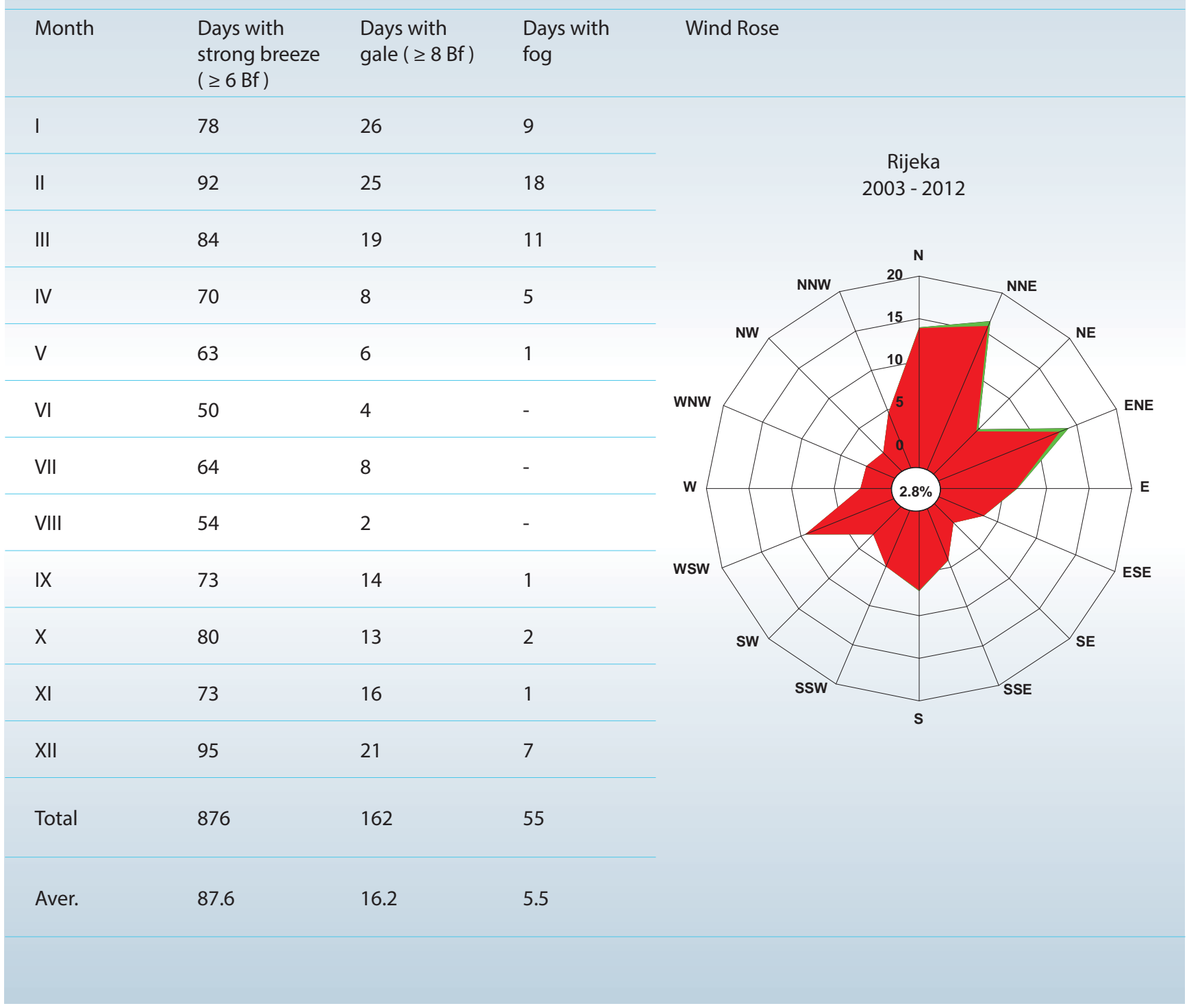




\subsection{Port of Zadar}

The port of Zadar handles coastal transport of passengers and cargo, warehousing and other transport-related operations.

Table 2.

Number of days with strong breeze ( $\geq 6 \mathrm{Bf}$ ) and gale force wind ( $\geq 8 \mathrm{Bf}$ ), number of days with fog and the wind rose for the area of Zadar, according to the data referring to the period from 2003 to 2012 .

\section{ZADAR 2003-2012}

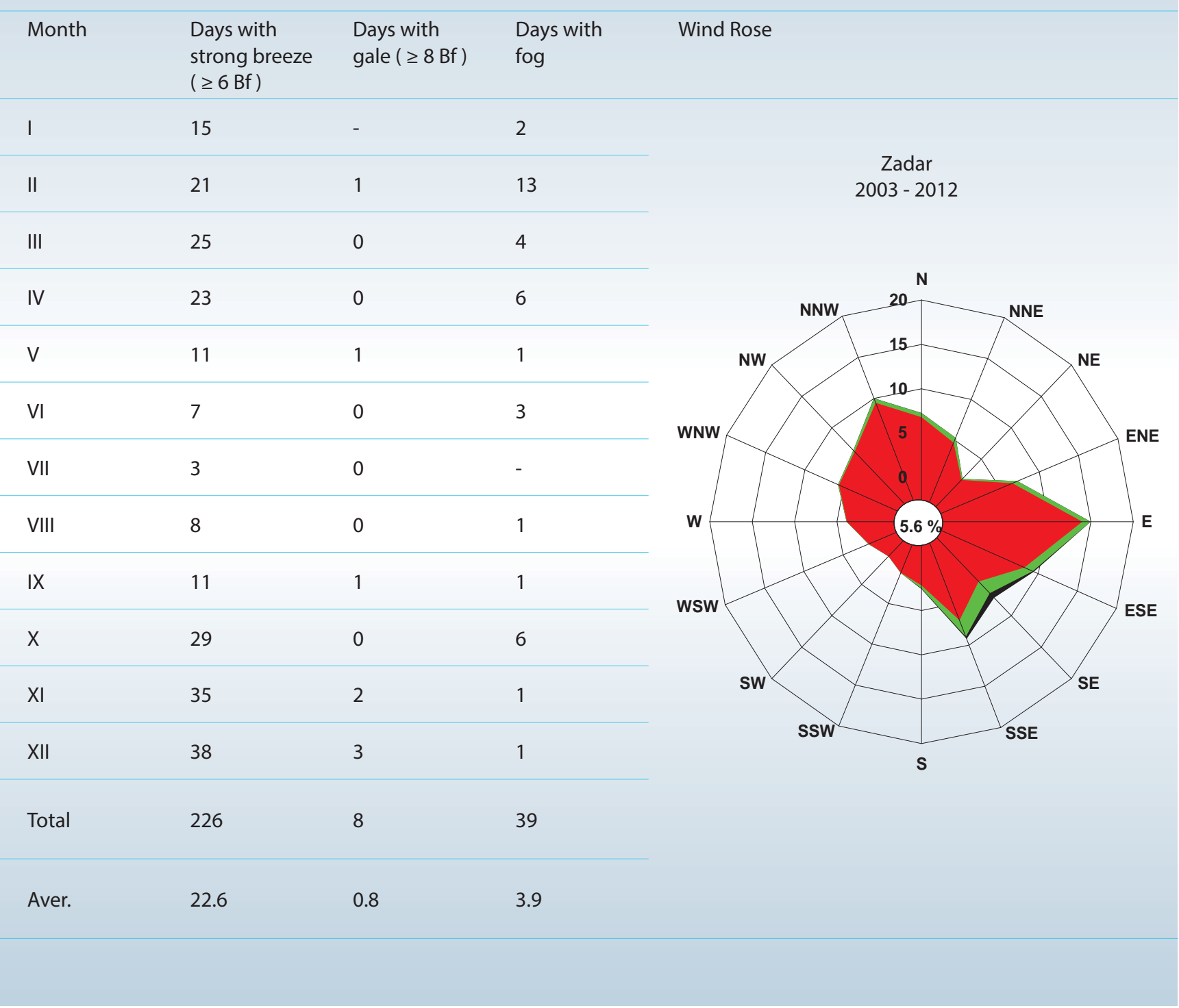




\subsection{Port of Split}

The port of Split features a favourable geographical and traffic position and is an intersection of several important transport corridors that connect the entire Mediterranean basin.

Table 3.

Number of days with strong breeze ( $\geq 6 \mathrm{Bf}$ ) and gale force wind ( $\geq 8 \mathrm{Bf}$ ), number of days with fog and the wind rose for the area of Split, according to the data referring to the period from 2003 to 2012.

\section{SPLIT 2003-2012}

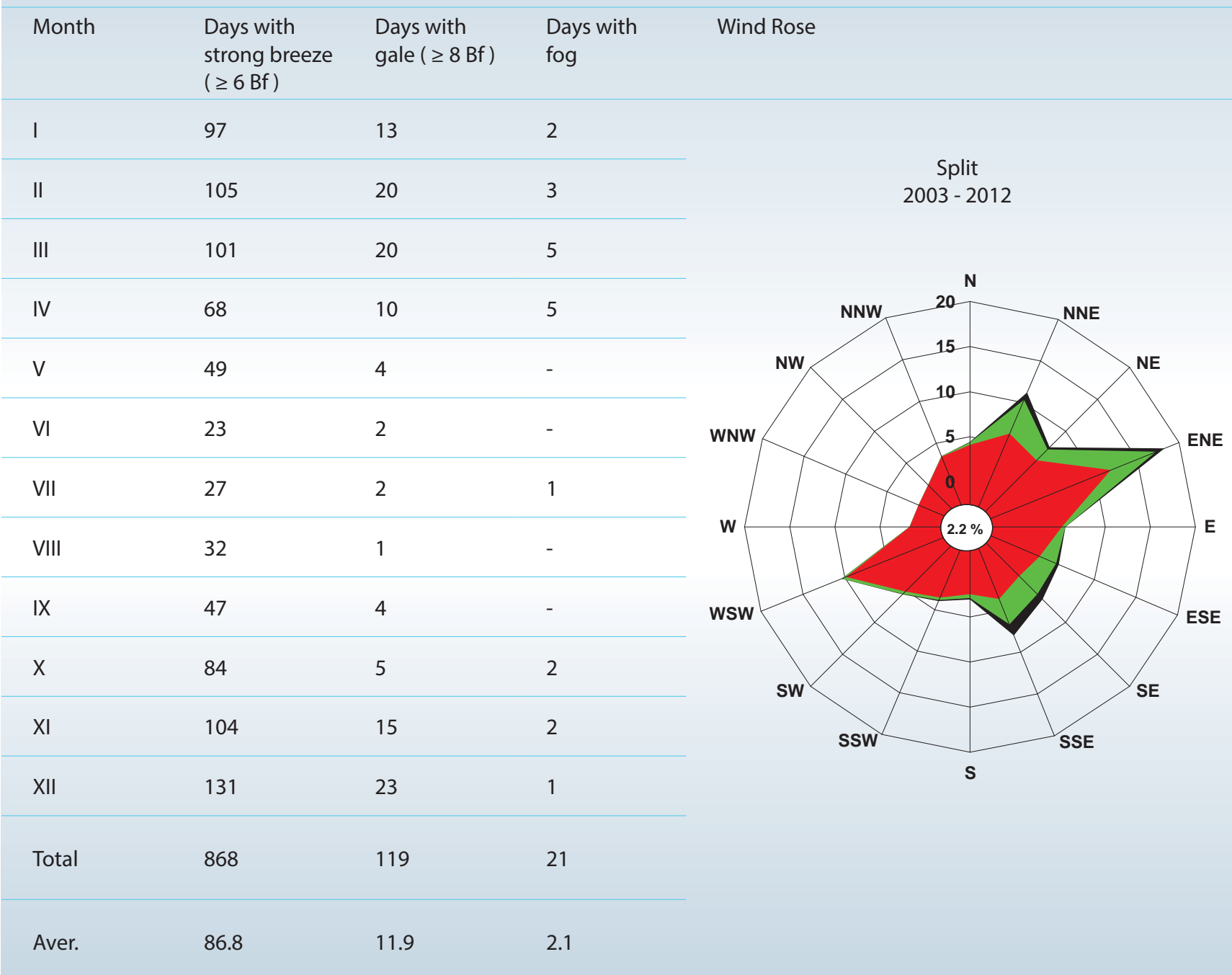




\subsection{Port of Ploče}

The port of Ploče plays a major role on the transit port service market and has objective capacities to attract cargo from other countries in the hinterland, which forms the basis for its successful further development.

Table 4.

Number of days with strong breeze ( $\geq 6 \mathrm{Bf}$ ) and gale force wind ( $\geq 8 \mathrm{Bf}$ ), number of days with fog and the wind rose for the area of Ploče, according to the data referring to the period from 2003 to 2012.

\section{PLOČE 2003-2012}

\begin{tabular}{|c|c|c|c|c|c|c|}
\hline Month & $\begin{array}{l}\text { Days with } \\
\text { strong breeze } \\
\text { ( } \geq 6 \mathrm{Bf} \text { ) }\end{array}$ & $\begin{array}{l}\text { Days with } \\
\text { gale ( } \geq 8 \text { Bf) }\end{array}$ & $\begin{array}{l}\text { Days with } \\
\text { fog }\end{array}$ & Wind Rose & & \\
\hline I & 32 & 3 & 3 & & & \\
\hline II & 34 & 3 & 3 & & $\begin{array}{c}\text { Ploče } \\
2003-2012\end{array}$ & \\
\hline III & 39 & 5 & 6 & & & \\
\hline IV & 22 & 1 & 2 & & & \\
\hline V & 17 & 0 & - & & & \\
\hline $\mathrm{VI}$ & 9 & 1 & - & WNW & & ENE \\
\hline VII & 17 & 1 & - & w & & $E$ \\
\hline VIII & 10 & 1 & - & & & \\
\hline IX & 6 & 0 & 1 & & & \\
\hline$x$ & 30 & 3 & 9 & & & \\
\hline XI & 25 & 7 & 11 & & $\mathrm{~s}$ & \\
\hline XII & 37 & 9 & 2 & & & \\
\hline Total & 278 & 34 & 37 & & & \\
\hline Aver. & 27.8 & 3.4 & 3.7 & & & \\
\hline
\end{tabular}




\subsection{Port of Dubrovnik}

The port of Dubrovnik developed at the south-eastern coast of the Adriatic Sea where the eastern Adriatic chain of islands ends and high seas begin.

Table 5.

Number of days with strong breeze ( $\geq 6 \mathrm{Bf}$ ) and gale force wind ( $\geq 8 \mathrm{Bf}$ ), number of days with fog and the wind rose for the area of Dubrovnik, according to the data referring to the period from 2003 to 2012.

\section{DUBROVNIK 2003-2012}

\begin{tabular}{|c|c|c|c|c|c|c|}
\hline Month & $\begin{array}{l}\text { Days with } \\
\text { strong breeze } \\
\text { ( } \geq 6 \mathrm{Bf} \text { ) }\end{array}$ & $\begin{array}{l}\text { Days with } \\
\text { gale ( } \geq 8 \text { Bf) }\end{array}$ & $\begin{array}{l}\text { Days with } \\
\text { fog }\end{array}$ & Wind Rose & & \\
\hline I & 148 & 47 & - & & & \\
\hline II & 149 & 40 & - & & $\begin{array}{c}\text { Dubrovnik } \\
2003-2012\end{array}$ & \\
\hline III & 143 & 43 & - & & $\mathbf{N}$ & \\
\hline IV & 109 & 13 & 3 & & & \\
\hline V & 109 & 9 & 1 & & & \\
\hline VI & 82 & 2 & 1 & WNW & & ENE \\
\hline VII & 94 & 3 & - & $w$ & & E \\
\hline VIII & 93 & 6 & - & & & \\
\hline IX & 121 & 17 & 1 & & & \\
\hline$x$ & 122 & 24 & - & & & \\
\hline XI & 131 & 57 & - & & & \\
\hline XII & 157 & 60 & - & & & \\
\hline Total & 1458 & 321 & 6 & & & \\
\hline Aver. & 145.8 & 32.1 & 0.6 & & & \\
\hline
\end{tabular}


The analysis of the above climatological data for the period from 2003 to 2012 shows that the port of Dubrovnik has the highest number of days with strong breeze ( $\geq 6 \mathrm{Bf}$ ) and gale force wind ( $\geq 8 \mathrm{Bf}$ ), but has the least days of fog. Due to frequent winds of strong breeze and gale force there might be difficulties in handling operations inside and outside the port, therefore the port activities should be adjusted to the meteorological conditions. The port of Rijeka is in the area with the highest average of foggy days in the Adriatic, which also represents a meteorological parameter that can obstruct port operations. The tables show that the prevailing winds in the observed ports come from NNE, except in the port of Zadar where the prevailing wind blows from E. In the port of Split, strong breezes ( $\geq 10.7 \mathrm{~m} / \mathrm{s}$ ) come most frequently from ENE direction, whereas in the port of Dubrovnik they blow from NNE direction.

Maritime meteorology plays an important role in passage planning, particularly in selecting the sailing route and the departure timing. Efficient maritime transport operations depend to a large extent on the amount, quality and speed of obtaining meteorological notices, warnings and information. It is evident that the influence of weather conditions on navigation is the strongest during winter. Storms and strong winds, high seas and poor visibility directly affect the operations of approaching and entering the ports. Pronouncedly rough sea with strong wind gusts and wave pounding may shift the vessel's cargo or even damage the holds, thus affecting the vessel's trim and stability.

The results produced through this research should therefore be taken into consideration when planning the yearround exploitation of ports, in order to achieve safer navigation and performance of port operations, and to reduce costs resulting from using ports in adverse weather conditions.

\section{CONCLUSION}

In modern maritime trade operations it is essential to bring a vessel from one port to another safely, taking into consideration the length of the voyage and the safety of the cargo and people on board. The factors that affect the safety of the passage include the familiarisation with all relevant meteorological aspects before navigation and the follow-up of the development of weather conditions when under way. These activities are supported by well organised local and global meteorological services.

The meteorological safety of navigation in the Republic of Croatia is within the competence of Croatian Maritime Meteorological Service (CMMS) in Split which is the department of Meteorological and Hydrological Institute of Croatia. Forecasts, reports and warnings are disseminated through VHF messages via three Coast Radio Stations (CRS Rijeka, CRS Split and CRS Dubrovnik). This paper presents a detailed overview and analysis of the climatological conditions, including the wind roses, for Croatia's five largest seaports: Rijeka, Zadar, Split, Ploče and
Dubrovnik. Further research into this matter is recommended in order to explore in more detail the correlation between the climatological elements and operational and safety aspects and the possible influence of climatological conditions on the economy and operational efficiency of these ports.

With regard to the overall political and economic situation across the world, it is evident that the level of development of the multimodal transportation in the Republic of Croatia is not satisfactory yet, so that there is large room and need for growth. Multimodal transport represents an important economic factor in connecting Croatia with Europe and the rest of the world. Therefore, both the short-term and long-term planning of the development of multimodal operations should be directed towards permanent enhancement of information and services in all segments of transport, including the segment of marine meteorology.

\section{REFERENCES}

Dubrović, E. (ed.), (2001), Riječka luka - povijest, izgradnja, promet, Rijeka: Muzej grada Rijeke.

Državni hidrometeorološki zavod Hrvatske (Meteorological and Hydrological Institute of Croatia), Intranet, Zagreb

Gelo B., (1992), Meteorološko osiguranje plovidbe morem i unutrašnjim vodama, Zbornik FPS, 13(1), pp. 6.

Gelo B., (2000), Opća i prometna meteorologija, Il dio, Zagreb: Hinus.

Luka Gaženica, (in Croatian), available at: http://www.057info.hr/ gospodarstvo/2009-05-04/luka-zadar-gazenica, [accessed 28 September 2013.]

Popović, R., (2010), Pomorska meteorologija u službi luka istočne obale Jadrana, Proceedings of the I. conference with international peer review "Transport i savremeni uslovi poslovanja (Transport and modern business conditions)", Vlašić, B\&H, May $27-28$

Popović, R. and Kulović, M., (2011), Meteorological safety of navigation, 15th International Conference on Transport Science, May 28, Portorož, Slovenia.

Popović, R., Kulović, M. and Šore, Ž., (2012), Meteorological warnings in the safety of navigation system, 4th International Maritime Science Conference, June 16th-17th, Split, Croatia, pp. 304-312.

Port of Rijeka, web page, available at: http://www.lukarijeka.hr/, [accessed 28 September 2013.].

Port of Split, home page, available at: http://www.lukasplit.hr/, [accessed 28 September 2013.].

Port of Ploče, home page, available at: http://www.luka-ploce.hr/, [accessed 28 September 2013.].

Port of Dubrovnik, home page, available at: http://www.portdubrovnik.hr/, [accessed 28 September 2013.].

WMO, (1981), Manual on Marine Meteorological Services (MMS-558).

WMO, (1981), Tehnical Regulation: Vol I - Global Aspects. 